\title{
The Partisan Politics of Family and Labor Market Policy Reforms in Southern Europe
}

Reto Bürgisser, University of Zurich

April 2022

\begin{abstract}
This chapter sheds light on the role of political parties as social investment protagonists, consenters, or antagonists in the reform of labor market and family policies in Greece, Italy, Portugal, and Spain. Drawing on original, hand-coded data of three decades of labor market and family policy reforms in Southern Europe, the findings show divergent social investment trajectories. While Spain and Portugal have started to develop contours of a social investment agenda, little progress has been made in Italy and Greece. Programmatic political competition and government partisanship play a role in accounting for these divergent trajectories. Centerleft parties have acted as the primary social investment protagonists in Spain, Portugal, and Italy. However, the Italian center-left remains fragmented and has rarely been in government. In stark contrast, both center-right and center-left parties in Greece have acted as social investment antagonists. Political and economic turmoil in the wake of the Eurozone crisis paint a bleak picture for the further development of social investment in Southern Europe. Once fiscal constraints can eventually be overcome, a core question remains to what extent an inclusive social investment coalition can be formed in an ever more fragmented political landscape.
\end{abstract}

Keywords: social investment; social compensation; Southern Europe; family policy; labor market policy; activation; government partisanship

Cite as:

Bürgisser, R. 2022. The Partisan Politics of Family and Labor Market Policy Reforms in Southern Europe. In: Garritzmann, J., S. Häusermann, and B. Palier (eds.). The World Politics of Social Investment (Volume II): The Politics of Varying Social Investment Strategies. Oxford: Oxford University Press, pp. 86107. 


\section{Introduction}

The previous chapters have analyzed the contested sustainability of social investment in Northern Europe, and the contentious politics of their development in Western European countries (see chapters 2 and 3 of this volume, Horn and van Kersbergen [2021], Busemeyer and Garritzmann [2021]). This chapter focuses on the political reasons why Southern European countries are social investment laggards. Despite the generally massive underprovision of policies supporting human capabilities, the extent of recent social investment reforms varies across Southern Europe. While Spain and Portugal have introduced some promising policies, Greece and Italy remain the ultimate laggards and an adverse case in the study of social investment (Kazepov \& Ranci, 2017).

The chapter aims to shed light on the role of political parties in the reform of labor market and family policies in the four biggest Southern European countries (Greece, Italy, Portugal, and Spain). While other policy fields such as pension or healthcare are mainly concerned with cost containment under the weight of economic and demographic pressures, labor market and family policies are the most innovative fields of social policymaking since the 1990s and allow us to study social investment trajectories.

Drawing on original, hand-coded data of all labor market and family policy reforms enacted in Southern Europe from 1990 to 2016, this chapter identifies which political parties are social investment protagonists, consenters, or antagonists. The findings show that programmatic political competition and government partisanship play a role in accounting for divergent social investment trajectories. Center-left parties have acted as the primary social investment protagonists in Spain, Portugal, and Italy. However, the Italian center-left remains fragmented and has rarely been in government. In stark contrast, both center-right and center-left parties in Greece have acted as social investment antagonists.

This chapter proceeds with a brief discussion of the Southern European model of welfare. Subsequently, the policy-based measure of welfare state change is discussed before presenting the results. The chapter concludes with a summary and outlook. 


\section{The Southern European Models of Welfare}

Esping-Andersen (1990) famously classified Southern European countries as conservative welfare states based on their idea of status preservation and the traditional male-breadwinner model. Shortly after, several studies argued that Southern European countries share characteristics that distinguish them from other regimes (see Ferrera, 1996; Leibfried, 1993; Rhodes, 1997). Most notably, Ferrera (1996) identified specific traits of these countries: fragmented income maintenance system, almost universal healthcare, low state capacity rooted in the absence of a Weberian public administration, and clientelism.

Joint institutional characteristics are also relevant regarding their consumption-oriented social expenditure profile. Institutional legacies of welfare state fragmentation and an investment/consumption ratio tilted towards consumption negatively affect the likelihood of introducing new policies addressing new social risks, especially through social investment (as developed in chapter 2 in volume I, see Häusermann et al. [2021]). Particularly the pensionheavy welfare states can crowd out other social spending in times of limited resources (Matsaganis, 2005). Due to their late industrialization and aging population, Southern European countries have also been particularly ill-prepared structurally to cope with the challenges of a postindustrial society (Bonoli, 2007). Besides, Southern European labor markets until the 1980s were strictly regulated. Employment protection has been a functional equivalent of underdeveloped and fragmented passive labor market policies, at least for parts of the workforce (Bonoli, 2003). Since the 1990s, however, labor markets have been substantially deregulated at the margins and are nowadays characterized by a strong dualization between well-protected insiders and precariously employed or unemployed outsiders (Emmenegger et al., 2012). Even though labor market dualization affects all postindustrial economies, it is particularly pronounced in Southern Europe (Bürgisser \& Kurer, 2019), and the interaction with fragmented social insurance models further exacerbates insider-outsider divides.

Another defining feature of Southern European countries is the pivotal role of families as welfare providers (Naldini, 2003). State support for families is limited, and the state only intervenes if the family's ability to cope with strain is exhausted. Furthermore, the influential role of religion has further blocked the development of family policies. Historically, the churches had a central role in the provision of welfare and, particularly, issues concerning family and education (Morgan, 2006). Family allowances were the cornerstone of family 
policy for a long time. Maternity leave developed only incrementally, while flexible options of shared parental leave were rarely debated. The church and the traditional male breadwinner model also prevented the development of childcare services for children below three years of age. Instead, governments mainly focused on expanding pre-school education for children above three years of age.

Beyond institutional legacies, historical and structural preconditions create a difficult terrain for social investment politicization and reforms. Except for Italy, Southern European countries are late democratizers. Hence, they share a rather recent history of authoritarianism, and they joined the European Union at a similar, late, point in time. Moreover, the occupational structures are typical for late industrializers with an only weakly developed knowledge economy and hence a relatively low demand for high-skilled labor (see chapter 8 by Garritzmann et al. [2021] in volume I). Consequently, the size of the new middle class is much smaller compared to other European countries (see chapter 12 by Bremer [2021] in volume I) and likely translates in lower societal demand for social investment (see chapter 3 of this volume, Busemeyer \& Garritzmann [2021]). More recently, Southern European countries also struggled with the process of Europeanization and the pressures of the European Monetary Union (EMU), especially during the Eurozone crisis.

In sum, institutional legacies have contributed to and interacted with a structural and economic context of weak societal demand and tight fiscal constraints, which in sum are particularly unfavorable to the politicization of social investment, let alone encompassing policy reforms. Despite Southern Europe being an unlikely case to study the social investment turn, some social investment reforms took place. The dire conditions under which social investment initiatives happen make Southern Europe an interesting case for analyzing party politics. The numerous obstacles and counterforces lead to particularly distinctive political positions in the public (as opposed to North-Western Europe where most of the public is generally supportive of social investment, see chapter 3 by Busemeyer and Garritzmann [2021] in this volume). Hence, this chapter sheds light on the relevant political protagonists, consenters, and antagonists in such reform processes. 


\section{A Policy-Based Measure of Welfare State Change}

The empirical analysis of this chapter is based on an original, hand-coded database that contains information on the policy content of all enacted labor market and family policy reforms in four Southern European countries from 1990 to 2016. In a first step, information on all the policy changes in the fields of employment protection legislation, passive and active labor market policy, early retirement, short-time work, leave policy, childcare, and family allowances and benefits were collected. The dataset contains information on 1'279 labor market policy changes enacted in 678 reforms and 143 family policy changes enacted in 80 reforms.

Based on the detailed policy information collected and, if available, evaluation reports and secondary literature on the specific reforms, each policy change has been coded in line with the overall theoretical framework of this volume (see chapter 2 in volume I, Häusermann et al. 2021). First, each policy change has been assigned a value of +1 if it expands, 0 if it does not affect, or -1 if it restricts social investment or social compensation policies. Second, each social investment policy change is distinguished by its overall function of either creating, mobilizing, or preserving human capabilities. Third, all identified social investment policies are coded by their distributive design, i.e., whether the policy change targets everyone (inclusive), only the low-income, poor, and precarious (targeted), or only more well-off beneficiaries (stratified).

In the field of labor market policy, passive labor market policies (PLMP), early retirement (ER), short-time work (STW), and employment protection legislation (EPL) count as social compensation policies. Active labor market policies (ALMP) are only coded as social investment if used as an instrument of upskilling, employment assistance, or public job creation. If ALMP reforms only strengthen commodification through sanctions and benefit conditionality (workfare), they are coded as restrictive on the social investment dimension (see also Bonoli, 2013). The primary function of upskilling programs is to create human capabilities; employment assistance programs mobilize human capabilities through placement services, counseling, and job subsidies; public job creation schemes and non-employment related training programs are geared towards preserving human capabilities.

In the field of family policy, family allowances (FA) are coded as traditional social compensation, while childcare (CC) and leave policies (LP) are coded as social investment 
(Morgan, 2012). However, leave policies are only coded as social investment as long as the goal is to improve well-paid and medium-length parental leave (max. 6 months) to preserve human capabilities. More extended leave has the opposite effect and likely prevents labor market reintegration. Childcare services have a double function of mobilizing human capabilities of the parents while at the same time creating human capabilities of children.

Finally, each policy change is weighted by 1 if it is a comprehensive reform that addresses the broader design of existing systems or by 0.5 if it is only a marginal change. In a final step, all the policy changes in one country-cabinet are aggregated to the sum effect of all policy changes in a given country-cabinet. Data collection and coding has proceeded in several steps to ensure that all relevant labor market and family policy reforms were included and coded correctly (for a detailed description of the data collection and coding, see Bürgisser, 2019).

The advantage of such a policy-based approach is that it minimizes potential confounding factors. It allows us to link the reform output more directly to the party in office, which is challenging to do with spending data where the impact of reforms usually become visible some years later only. Welfare entitlement datasets could be an alternative, but they are calculated only for a few groups of recipients (e.g., average production workers) and lack most social investment policies. Since this chapter focuses mainly on social investment policies and particularly on the politics of welfare state change, this policy-based approach allows for an encompassing, systematic, yet detailed analysis. It can be complemented with qualitative case studies to get more narrowly at the political and coalitional dynamics of reform negotiation (such as in chapter 5 in this volume by Ronchi and Vesan [2021] who study particular reforms in Italy).

\section{The Partisan Politics of Family and Labor Market Policy Reforms}

\section{Spain}

After the transition to democracy, the development of the Spanish welfare state before 1990 can be divided into two periods. The first period from 1975 until 1985 was characterized by the general expansion of social policy programs (Cabrero, 2011). Economic hardship, the focus on democratic consolidation, and a general weakness of societal actors demanding generous 
family policies meant that family policies were not high on the political agenda. The main political parties were not keen on politicizing the issue. During the late 1970s and the 1980s, the center-right parties upheld a very traditional view of the family and were content with the current male breadwinner policies focusing mainly on family allowances and short maternity leave. The center-left Spanish Socialist Workers' Party (PSOE), on the other hand, was afraid to push the issue of family policy, long associated with the pro-natalist and paternalist values of the Franco regime.

The second period of welfare state development from 1986 until 1995 was marked by welfare state consolidation. Public attention focused on chronically high unemployment rates and the public discourse slowly shifted towards labor market flexibility and the potentially adverse effects of generous unemployment benefits on labor market participation (Moreno, 2000). Family issues also became more politicized in the late 1980s. While parties intentionally avoided family policies before and considered family allowances a social security benefit and labor policy, work-family reconciliation appeared prominently on the PSOE platform in 1989 (Naldini, 2003).

The starting point of this analysis falls in the middle of this second period. Figures 4.1 and 4.2 show the direction of labor market and family policy reforms under each government since 1990. The third and fourth center-left González governments (1989-1996) were confronted with an acute economic crisis from 1992 to 1994. The third González government had slightly more fiscal leeway and still managed to implement ALMPs. The fourth González government, however, was confronted with massive budgetary pressures, scaled back PLMP and deregulated EPL. Hence, while the two earliest González governments (1982-1989, not in Figures 4.1 and 4.2) marked the high point of welfare state expansion in Spain, the severe economic crisis and the looming EMU access conditions led to a period of market liberalism. The only notable exception is the 1994 leave policy reform, which increased maternity leave (from 14 to 16 weeks) and the amount of the benefit (from 75 percent to 100 percent of the salary), making maternity leave one of the most generous in Europe (León, 2011). 


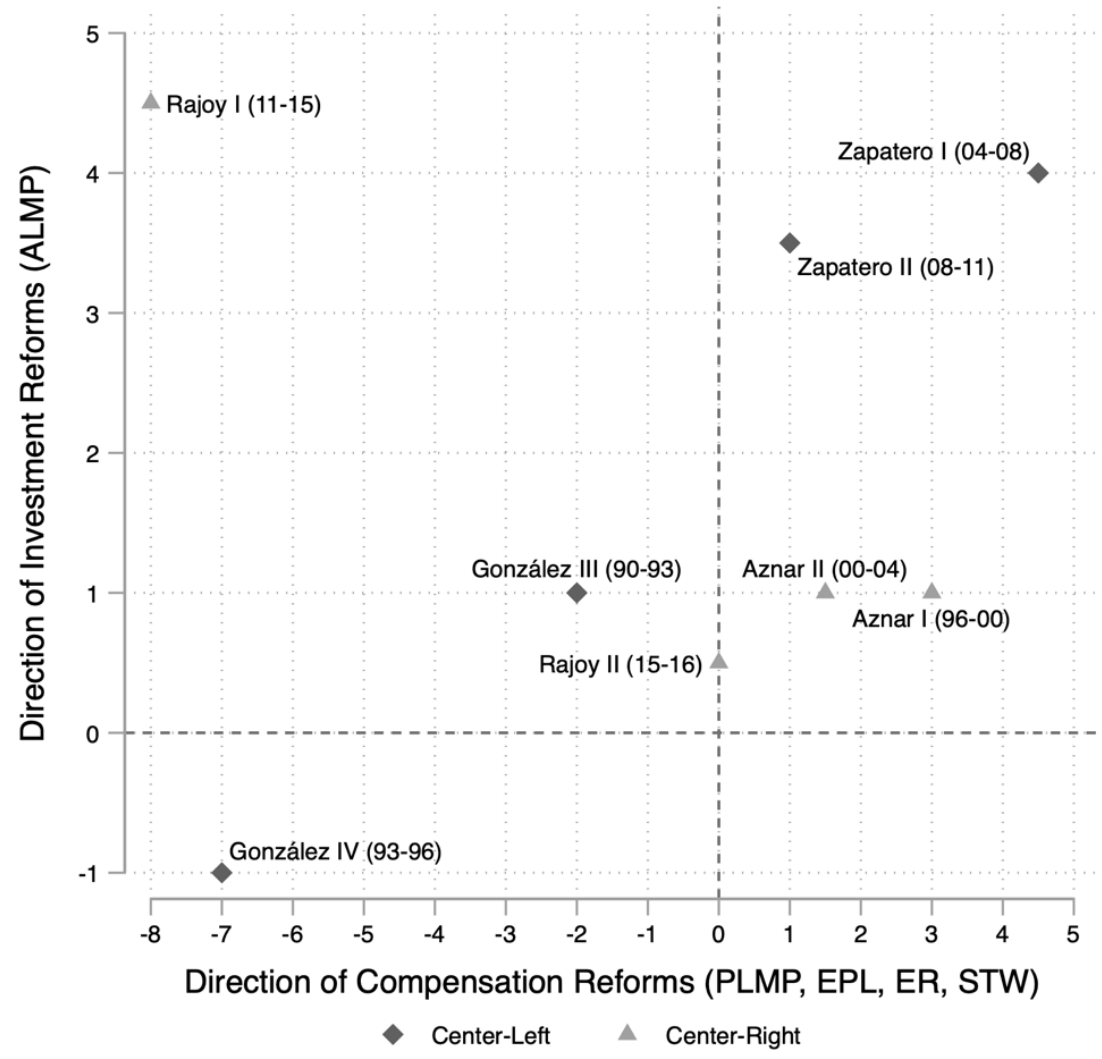

Figure 4.1: Labor Market Reforms in Spain by Cabinet

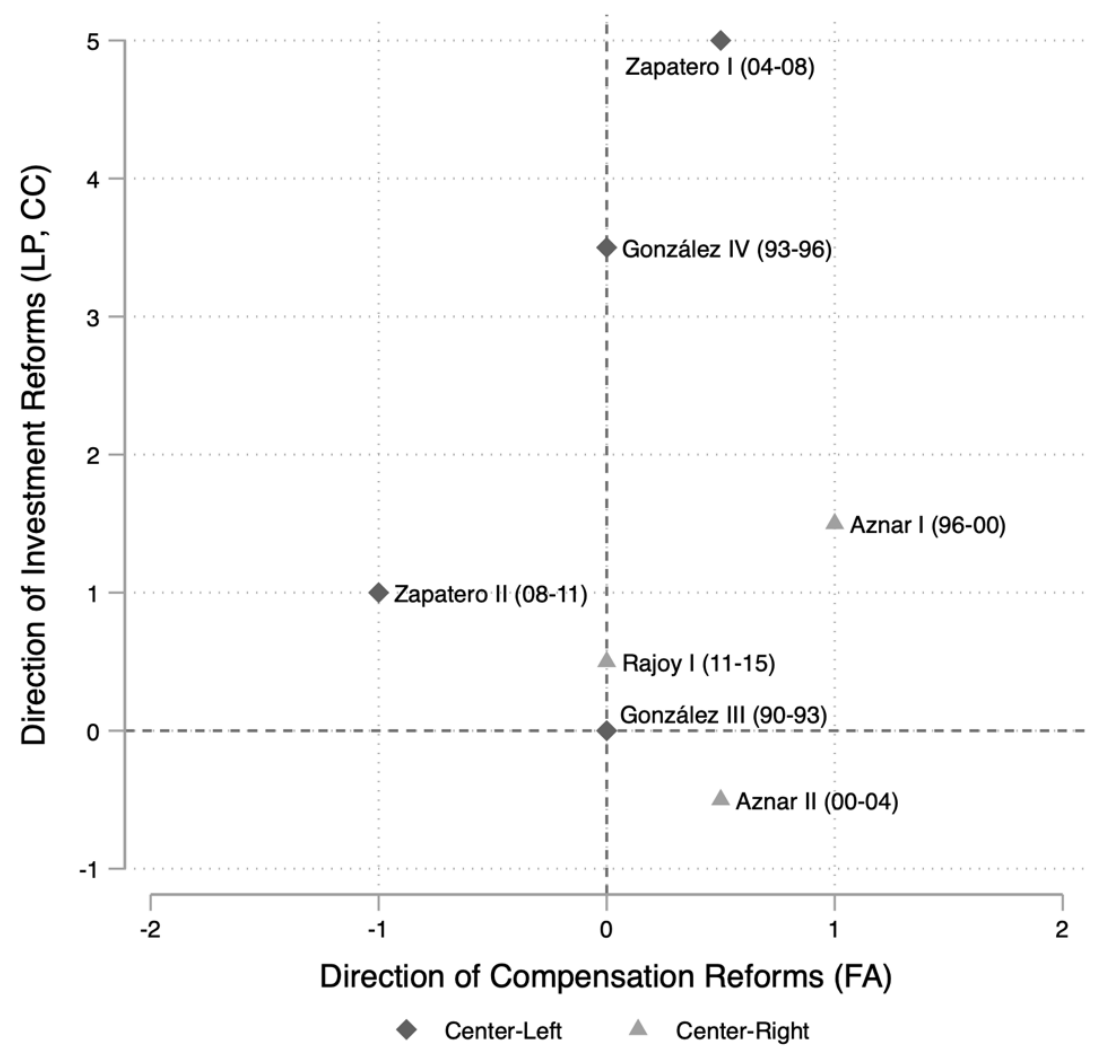

Figure 4.2: Family Policy Reforms in Spain by Cabinet 
Partially due to the controversial labor market reforms - restricting EPL and PLMP - enacted under González, PSOE lost the 1999 elections to the center-right People's Party (PP). The following eight years under Aznar (1996-2004) led to only small improvements in EPL and PLMP. Even though the sound economic development created more fiscal space during this period, there have also been a few expansive ALMP reforms. An activation approach has never been central to the platform of the Spanish PP. In the field of family policy, Aznar implemented some minor improvements in maternity leave and substantially increased family allowances. Moreover, the government deregulated early childcare services to expand the private market in childcare, leading to stratified access to childcare (Wall \& Escobedo, 2009).

The political pendulum swung back to the center-left PSOE in the 2004 election. Governing during an economic boom, the first Zapatero government (2004-2008) expanded both PLMPs and ALMPs, but the emphasis has been more on the latter, i.e., on social investment expansion. Zapatero was the first to put ALMPs properly on the agenda and introduced several new inclusive measures of upskilling the unemployed complemented with job subsidies. A central cornerstone of the Zapatero government was its emphasis on work-family reconciliation policies (León, 2011). Aznar's deregulation of childcare services was immediately revoked. A series of reforms attempted to break with the familialistic premise undergirding the Spanish welfare state (León, 2011), by providing universal pre-school education, better access to childcare services, and more public nursery schools. Moreover, maternity leave for more vulnerable groups was improved, and 15 fully paid days of paternity leave were introduced. Overall, the first term of Zapatero set the starting point of a potential recalibration of the Spanish welfare state towards more inclusive investment-oriented social policies focusing on the preservation, mobilization, and creation of human capabilities.

At the beginning of the second Zapatero government (2008-2011), Spain was still thriving thanks to low interest rates and the housing boom. In late 2008, however, the economic crisis has reached Spain. The crisis did not immediately lead to a wholesale retrenchment but to a short period of "emergency Keynesianism" with improved PLMPs and ALMPs. Towards the end of his tenure in 2010, however, Zapatero also enacted a controversial labor market reform that substantially deregulated EPL. Besides, some family allowances were reduced or abolished, and the extension of paternity leave was put on hold. 
Rajoy took office at the height of the Eurozone crisis in 2011 and immediately embarked on a path of market liberalism. Two reforms in 2012 have been the most severe cuts in EPL in Spanish history. Unlike previous deregulations at the margins, these reforms aimed at a fullscale liberalization of EPL for insiders and outsiders. ALMPs were exempted from cutbacks and continued to be improved, though Rajoy introduced more workfare elements into the activation system. Apart from the increase of paternity leave to four weeks, there have been no expansive changes in family policies. On the contrary, public funding and subsidies for childcare services were severely reduced in 2013, leading to a substantial increase in families' costs.

Overall, center-right governments in Spain showed little interest in social investment reforms. The center-right PP most strongly favored a strategy of market liberalism and reduced social compensation. PP has only recently started to support some leave policy reforms and a strategy of workfare activation. On the other hand, PSOE governments, especially under Zapatero, have introduced significant improvements in activation, leave policy, and childcare. Thus, the center-left PSOE acted as a social investment protagonist to preserve, mobilize, and create human capabilities. However, the Spanish case also illustrates the massive and tight constraints economic crises have inflicted on welfare state reforms, as a result of economic structural weaknesses and budget conditionality.

\section{Portugal}

The Portuguese welfare state developed remarkably different after the transition to democracy. In contrast to Spain, Portugal followed a liberal strategy of limited social protection (Watson, 2015). Unemployment coverage and generosity remained low until the late 1980s, while Spain followed a strategy to provide rural workers in their Southern regions with subsidies and generous unemployment benefits. As a result, Portugal witnessed a labor migration of rural workers into the cities, whereas rural workers in Spain could afford to remain in the countryside. In this period, Portugal increased labor force participation at the cost of rising in-work poverty and inequality, while Spain compressed the income distribution and sheltered against poverty at the cost of rising unemployment (Watson, 2015).

Unlike in Italy and Spain, the transition to democracy in Portugal led to a more immediate and direct rejection of the authoritarian regime's traditional gender roles and a strong push 
for gender equality. Political parties agreed to emphasize the state's responsibility to support a full-time dual-earner model, leading to a gradual increase in maternity leave, childcare services, and the early introduction of parental leave (Escobedo \& Wall, 2015). Female labor force participation in Portugal was already around 50 percent in 1990 compared to around 35 percent in Italy, Spain, and Greece. Due to high female labor force participation, a key challenge was to design family policies to better reconcile work and family life.

Figures 4.3 and 4.4 show the direction of labor market and family policy reforms under each Portuguese government since 1990. The second and third Silva government, belonging to the center-right Social Democratic Party (PSD), lasted until 1995 and barely enacted any labor market reforms and only slightly expanded maternity leave. In 1995, the center-left Socialist Party (PS) took office. The two Guterres governments (1995-2002) profited from strong economic growth and enabled the PS to implement additional PLMPs to improve the coverage and benefit levels of the existing system. Guterres also put for the first time an emphasis on ALMPs. However, activation was mainly geared towards employment assistance with a strong pro-market employment orientation and weak investment in human capabilities. Thus, the main goal was to mobilize human capabilities, not to create them through upskilling programs. Moreover, the first Guterres government increased well-paid maternity leave to 120 days and granted two weeks of fully compensated parental leave.

In contrast to the other Southern European countries, Portugal experienced an economic slump already in the early 2000s. The economic slowdown and rising unemployment rates put pressure on politicians to introduce significant reforms. The center-right Barroso government (2002-2004) followed a more market-liberal approach of EPL deregulation, workfare activation, and reduced family allowances, coupled with some improvements of PLMPs and maternity leave. Subsequently, the short-lived government of Santana Lopes (2004-2005) did not enact any remarkable labor market or family policy reforms. 


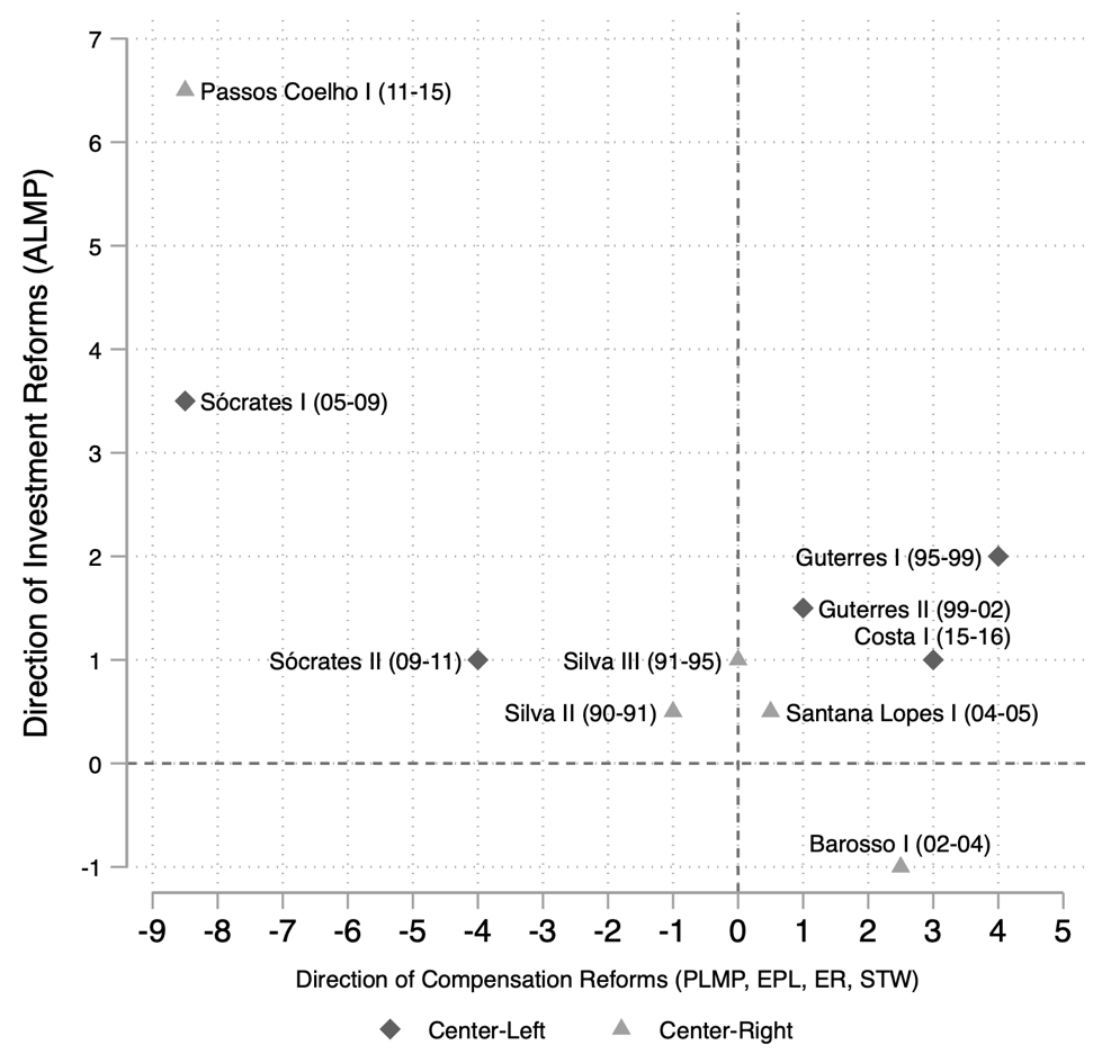

Figure 4.3: Labor Market Reforms in Portugal by Cabinet

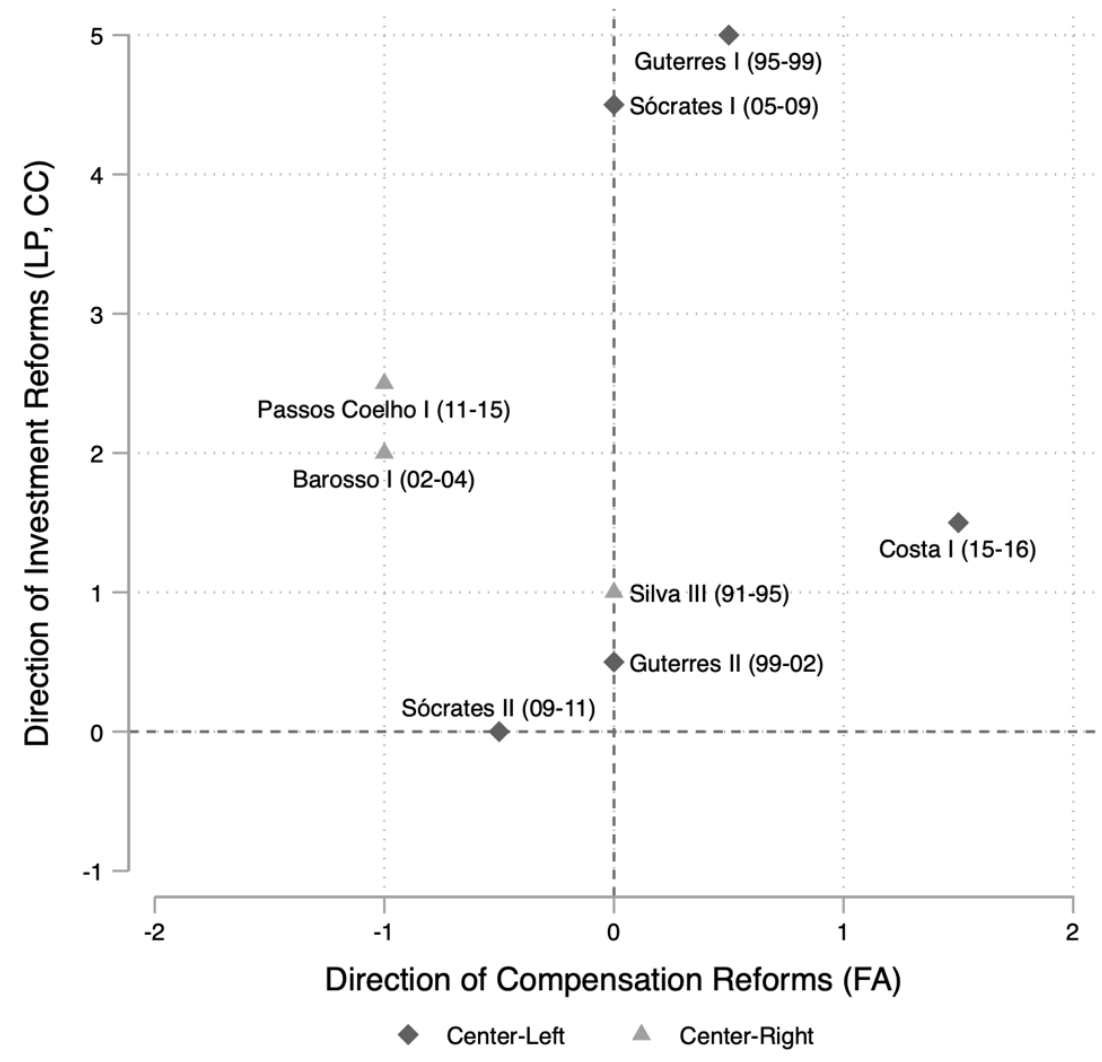

Figure 4.4: Family Policy Reforms in Portugal by Cabinet 
In stark contrast to the two previous Guterres governments, the first center-left Socrates government (2005-2009) had to cope with negative growth rates and rising unemployment. This led to a deregulation of EPL at the margins and a much less generous PLMPs (and early retirement). Despite this market-liberal approach to labor market compensation policies, however, Socrates significantly expanded ALMPs, especially with a much stronger focus on skill creation and preservation through upskilling and job creation schemes. Moreover, a more flexible parental leave scheme, allowing parents to share the leave period, was introduced, and paternity leave was increased. Hence, the first Socrates cabinet entailed the most pronounced and distinctive social investment agenda. Most of the second Socrates government (2009-2011) happened under the auspices of the Troika, which was ultimately the reason for Socrates' early resignation in 2011. The Memorandum of Understanding by the EMU Troika only allowed Socrates to improve ALMPs slightly, whereas pensions, PLMP, and EPL had to be cut (Theodoropoulou, 2014). Furthermore, a family allowance reform in 2010 changed the eligibility criteria by income levels, estimating that nearly half a million families lost access to the main family benefit while benefits amounts were reduced substantially for the others (Wall, 2016).

The center-right government under Passos Coelho (2011-2015) subsequently followed a similar path. He most strongly deregulated EPL, enacted further cuts to PLMPs, but also expanded ALMPs. However, there is a critical difference between the two governments. Activation reforms under Socrates aimed in no small extent at skill creation, whereas Passos Coelho focused almost exclusively on skill mobilization through job subsidy programs with a strong pro-market employment orientation. Moreover, Passos Coelho reduced family allowances, introduced minor improvements to parental leave, and approved the universal entitlement to ECEC for children from five to four years of age.

Overall, the deep and unpopular austerity measures implemented by Passos Coelho led to the demise of the PSD at the 2015 general election and to the rise of the first PS government in the history of Portugal that is supported by the radical left Portuguese Communist Party (PCP) and Left Bloc (BE). Even though it is too early to fully assess the changes under the Costa government, the focus right at the beginning of his tenure was on the reversal of the cuts to PLMPs, child benefits, and pensions. In strong disagreement with the Troika, Costa officially declared that his goal was to increase the citizens' consumption power in the hope to spur economic growth. In 2016, the Costa government also increased paternity leave to 25 days and announced the universal entitlement to ECEC from three years of age. 
Overall, the center-left PS governments improved both PLMPs and ALMPs during good economic times. When faced with an economic crisis, they tended to follow a more marketliberal approach of decreasing social compensation. However, center-left governments put a stronger focus on activation and family policies. In particular, it is mainly PS governments who acted as social investment protagonists addressing skill creation through upskilling programs and skill preservation through leave policy. Center-right governments acted instead as social investment consenters, increased workfare and employment assistance programs, and maintained the family policy system.

\section{Italy}

The executive dominance of Democrazia Cristiana (DC) for most of the post-war years has left a strong mark on the Italian political economy. For a long time, Democrazia Cristiana managed successfully to hold together a diverse set of constituencies in their coalition: welfare state expansion and better working conditions for the Northern workers; subsidies, public sector employment, and benefits for Southern state-dependents; no tax increases (and enforcement) for their traditional support base of small businesses (De Cecco, 2007). As a result, the growth of public expenditure was not accompanied by a parallel growth in tax revenues. Despite public deficits and public debt spiraling out of control in the 1970s and 1980s, deep reforms were inhibited by coalition governments' fragmented interests. Hence, tight budgetary constraints and political fragmentation have been essential conditions for Italian welfare politics early on.

The two main political actors of the post-war years, the Catholic DC and the Communists, had little interest in family policies. The topic was virtually absent from political discourse until the late 1960s (Naldini, 2003). Both actors were content with the fragmented system of family allowances, which mainly functioned as an income supplement to male breadwinner wages. The combination of wages and family allowances resulted in a family wage underpinning the male breadwinner model. The critical role of family allowances as a wage supplement is exemplified by the fact that public expenditure for family benefits was higher than for pensions in the early 1950s and only started to decline in the late 1960s after a series of reforms homogenizing and lowering benefit levels in favor of more generous pensions (Ferrera et al., 2013). Social movements put family issues back on the political agenda in the late 1960s. 
Politics responded with the introduction of kindergartens (1968), publicly funded daycare services (1971), and new maternity leave (1971). The daycare law aimed for childcare for children under the age of three, though enrollment remained very low: local authorities organized these services, they were not universally accessible, and parents had to pay part of the costs (Naldini, 2003). Unlike pre-school education, care for children under the age of three is considered personal social services and remains a family matter (Saraceno, 1994).

The highly fragmented and ideologically divided coalition government of five parties (pentapartito) made it challenging to implement significant social policy changes in the 1980s and resulted in minor changes catering to specific, targeted groups in a system of clientelistic exchanges (Naldini, 2003). Even though some political parties put family policy at the center of their social policy programs in the late 1980s, it remained mainly a rhetorical change. Apart from the establishment of a means-tested family allowance in 1988, no notable changes took place. The massive political corruption scandals (Tangentopoli/Mani Pulite) resulted in the party system's total breakdown and the demise of the First Republic in 1992. Thus, the starting point of this analysis is marked by tight budgetary constraints and high political instability. The latter is strongly related to a highly fragmented and unstable party system that splits the center-right and center-left block into multiple parties, making coalition building for reforms cumbersome and governments short-lived.

Figures 4.5 and 4.6 show the direction of labor market and family policy reforms under each Italian government since 1990. Due to the high political instability in the early 1990s, only a few reforms were introduced. The technocratic governments of Ciampi (1993) and Dini (1995) had an exclusive focus on reforming the electoral system combined with some fiscal reforms that did not affect labor market and family policies. In between, the short-lived first centerright Berlusconi government introduced a series of expansive PLMP reforms. He followed in the footsteps of earlier center-right governments who effectively used passive spending as a clientelistic tool to mobilize state dependents from the South as their electoral backbone. 


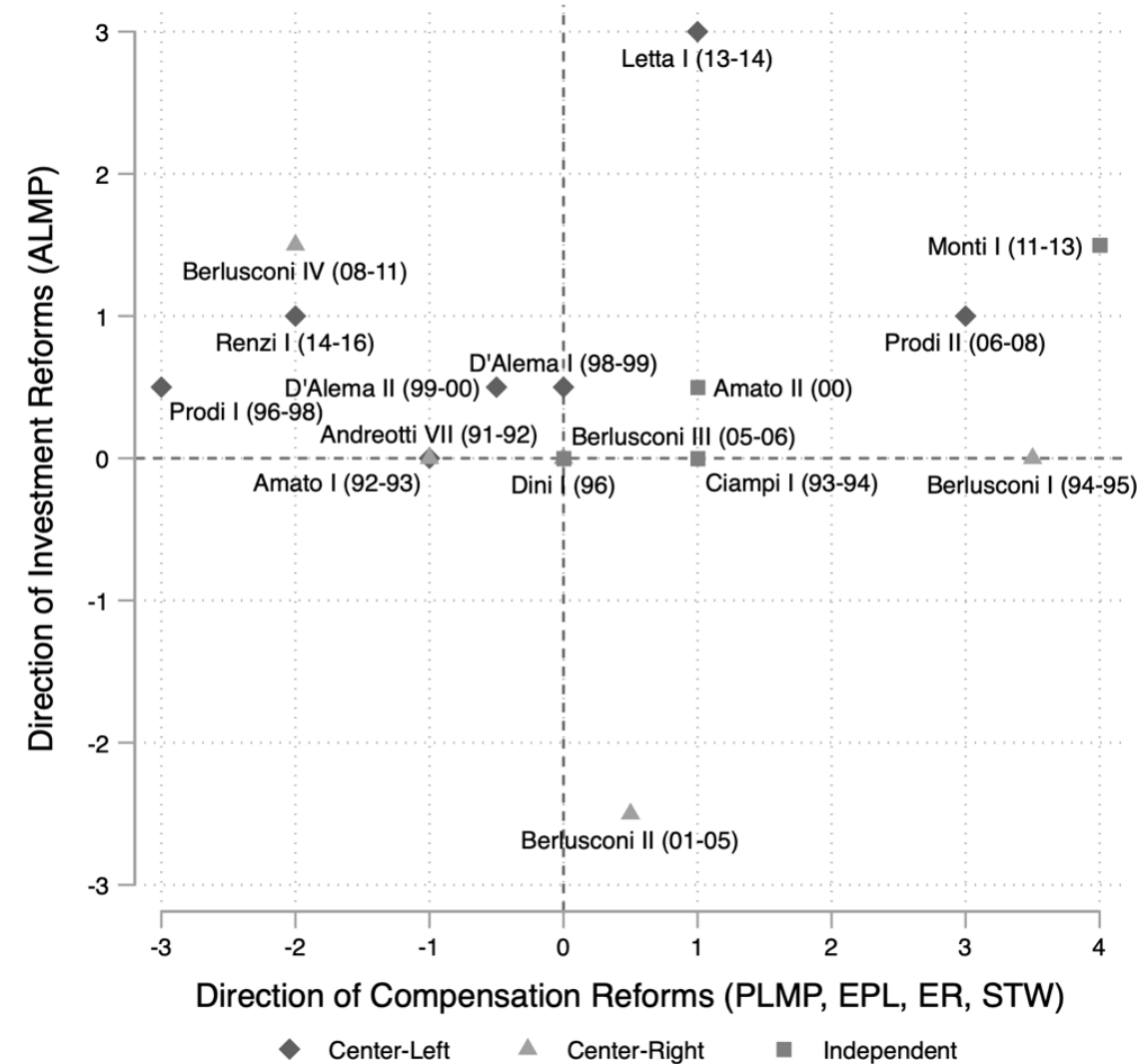

Figure 4.5: Labor Market Reforms in Italy by Cabinet

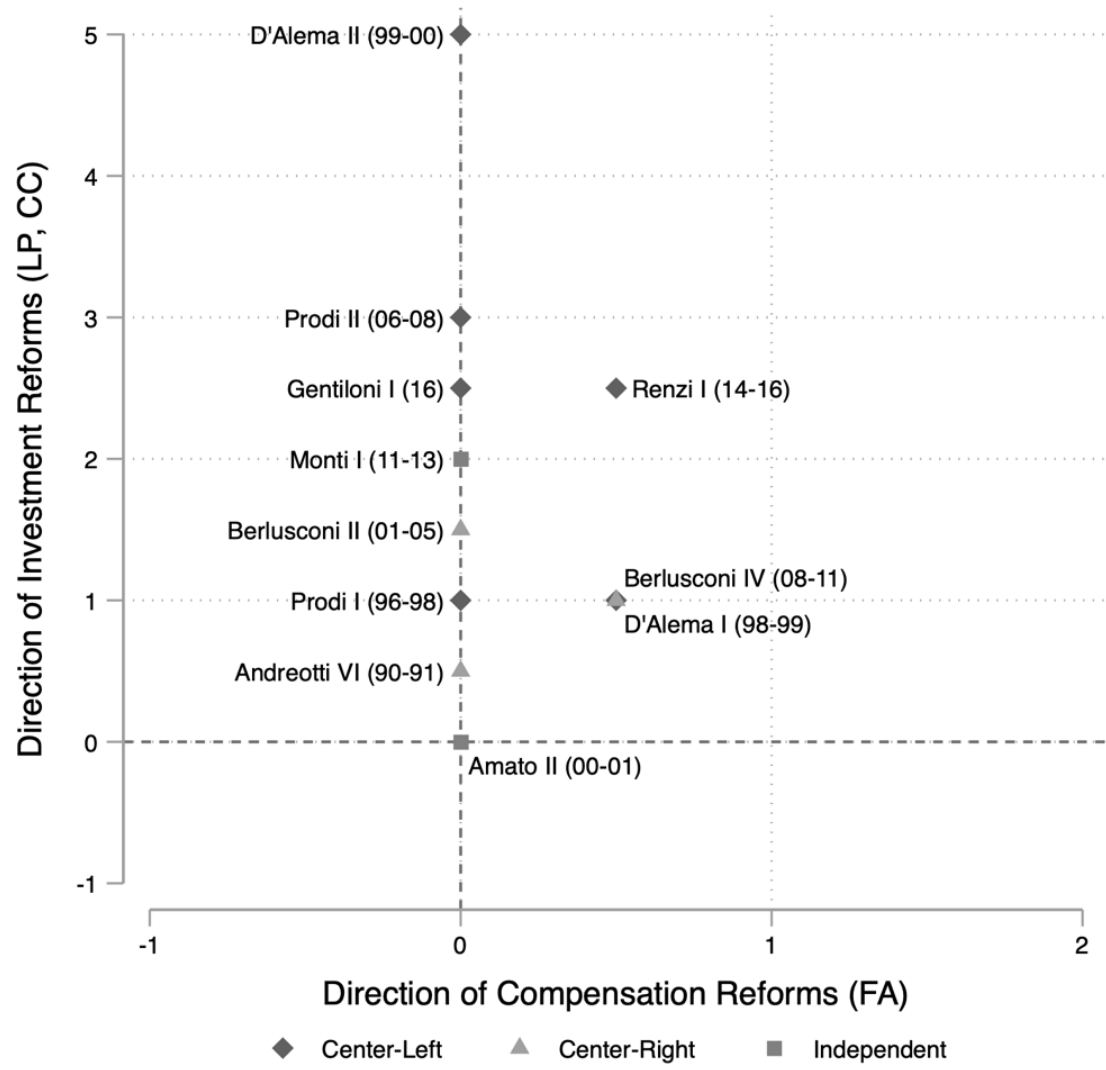

Figure 4.6: Family Policy Reforms in Italy by Cabinet 
From 1995 until 2001, the center-left governments in power (Prodi I, D'Alema I-II, Amato II) attempted to modernize labor markets (Ferrera \& Gualmini, 2004). Most notably, the 1997 Treu Reform under the first Prodi government significantly deregulated EPL at the margins. Some ALMPs reforms focusing on skill creation through upskilling programs took place, but they remained minimal. In a similar vein, the first Prodi government established a national fund for the development of childcare services, though only limited financial resources were assigned to implement it (Albertini \& Pavolini, 2015). The second D'Alema government substantially improved parental leave, made uptake more flexible, and improved maternity leave (Naldini \& Saraceno, 2008). Besides, a reform introduced the principle of universalism to childcare but was subsequently undermined in 2001 by the constitutional reform giving regions exclusive responsibility for childcare provision.

Once Italy joined the EMU, the low interest rates implied a massive relief on the debt service and much less pressure for structural reforms. The second and third Berlusconi governments (2001-2006) were thus governing in a favorable economic context. The Berlusconi cabinet started a series of changes in ALMPs, but it was mainly a workfare strategy of market liberalism through increasing incentive reinforcements and cannot be classified as social investment. The 2003 Biaggi reform further deregulated EPL at the margins. Instead of expanding childcare services, new legislation simply lowered the threshold for entering kindergarten from three to two and a half years. The following, though short-lived, second center-left Prodi government (2006-2008) partly reregulated temporary job protection and enacted expansive PLMP reforms. Again, the Prodi cabinet prioritized ALMPs geared towards skill creation through training programs for the unemployed. The cabinet also invested more financial resources in childcare facilities development, and leave policies were slightly expanded.

With the onset of the Great Recession, the fourth Berlusconi government (2008-2011) responded with immediate crisis measures. The cabinet enacted some short-time work schemes, expanded family allowances, implemented employment assistance programs with a strong pro-market orientation, and further deregulated EPL at the margins. Due to mounting pressure, Berlusconi stepped down and the technocratic Monti government took office with an ambitious reform program in November 2011. Given that the Monti cabinet ended the indexation of pensions, increased minimum retirement age, and liberalized protected product markets (Culpepper, 2014), it might be a surprise that the Monti government is located in the upper right quadrant in Figure 4.5. However, the Monti 
government has indeed enacted expansive ALMP and PLMP reforms. It started a process that was later pursued by the center-left Letta and Renzi governments (for a more detailed case study, see chapter 5 by Ronchi \& Vesan [2021] in this volume). EPL deregulation is combined with widening the access to unemployment benefits to previously excluded groups and some expansion of ALMPs. The Monti-Fornero Reform and Renzi's Jobs Act are the archetypes of such a recalibrating reform strategy (Sacchi, 2018). Besides, the Monti, Renzi, and Gentiloni cabinets expanded leave policy and access to childcare services through voucher systems and yearly lump sum contributions to daycare fees.

Compared to the other Southern European countries, Italy's most distinguishing features are the high levels of political instability, the fragmentation of the center-left, and the short periods the center-left has been in power during the last three decades. Center-right governments have shown little interest in activation, childcare, and leave policies, and they have often even acted as social investment antagonists. The few positive social investment developments took place almost exclusively under center-left governments. Due to government instability and fiscal constraints, however, their reform proposals never marked a significant policy shift. Since center-right parties have dominated politics most of the time in Italy, passive measures still dominate labor market policies and activation and family policies remain underdeveloped (see also Bonoli, 2013).

\section{Greece}

Unlike in Continental European countries, the strong economic growth in the 1950s and 1960s did not translate into the expansion of the Greek welfare state. Social insurance coverage remained fragmented and unequal. The period of authoritarian rule (1967-1974) did not lead to any significant changes in this regard. After the transition to democracy, four fully paid weeks and eight flat-rate weeks of job-protected maternity leave were introduced in 1969, and maternity leave became fully paid for 12 weeks by 1997. With the center-left Panhellenic Socialist Movement (PASOK) entering office in 1981, social expenditures substantially increased (Featherstone \& Papadimitriou, 2015; Matsaganis, 2011). However, the phase of welfare state expansion in the 1980s also allowed political actors to use social policies as an instrument to establish clientelistic exchanges (Petmesidou, 2017). At the starting point of the data in 1990, the Greek welfare state was characterized by the main features Ferrera (1996) described as the Southern European welfare regime: highly fragmented social insurance, 
pension-biased spending, underdeveloped social safety nets, high prevalence of clientelism and inefficient public bureaucracies.

Figures 4.7 and 4.8 show the direction of labor market and family policy reforms under each Greek government since 1990. The center-right New Democracy (ND) government under Mitsotakis (1990-1993) barely enacted any reforms, except for two small activation reforms and an extension of maternity leave to 16 weeks. The 1993 election led to the return of the center-left PASOK for the next ten years. While the Papandreou A and the first Simitis governments were rather short-lived and did not enact any substantial reforms, the second Simitis government (1996-2000) introduced several smaller activation reforms aimed at reintegrating the unemployed through employment assistance programs (skill mobilization) and a first training program for the unemployed (skill creation). However, financial resources attached to these programs were limited. Moreover, paid maternity leave was increased to 17 weeks, and two fully paid days of paternity leave were introduced. The third Simitis government (2000-2004) started to deregulate EPL and legally introduced the practice of temporary employment. The government also enacted some expansive ALMP reforms directed at employment assistance and job subsidies.

PASOK lost the 2004 general elections and the center-right ND government of Karamanlis Kos entered office. During both terms (2004-2009), unemployment benefits were increased, stricter regulations on the use of temporary work contracts were introduced, some activation measures geared towards employment assistance and job subsidies were enacted, and maternity leave was further expanded. In addition, a targeted reform aimed at making childcare facilities more accessible and financially affordable, though only a limited amount of people will benefit from these changes due to the limited financial resources allocated. 


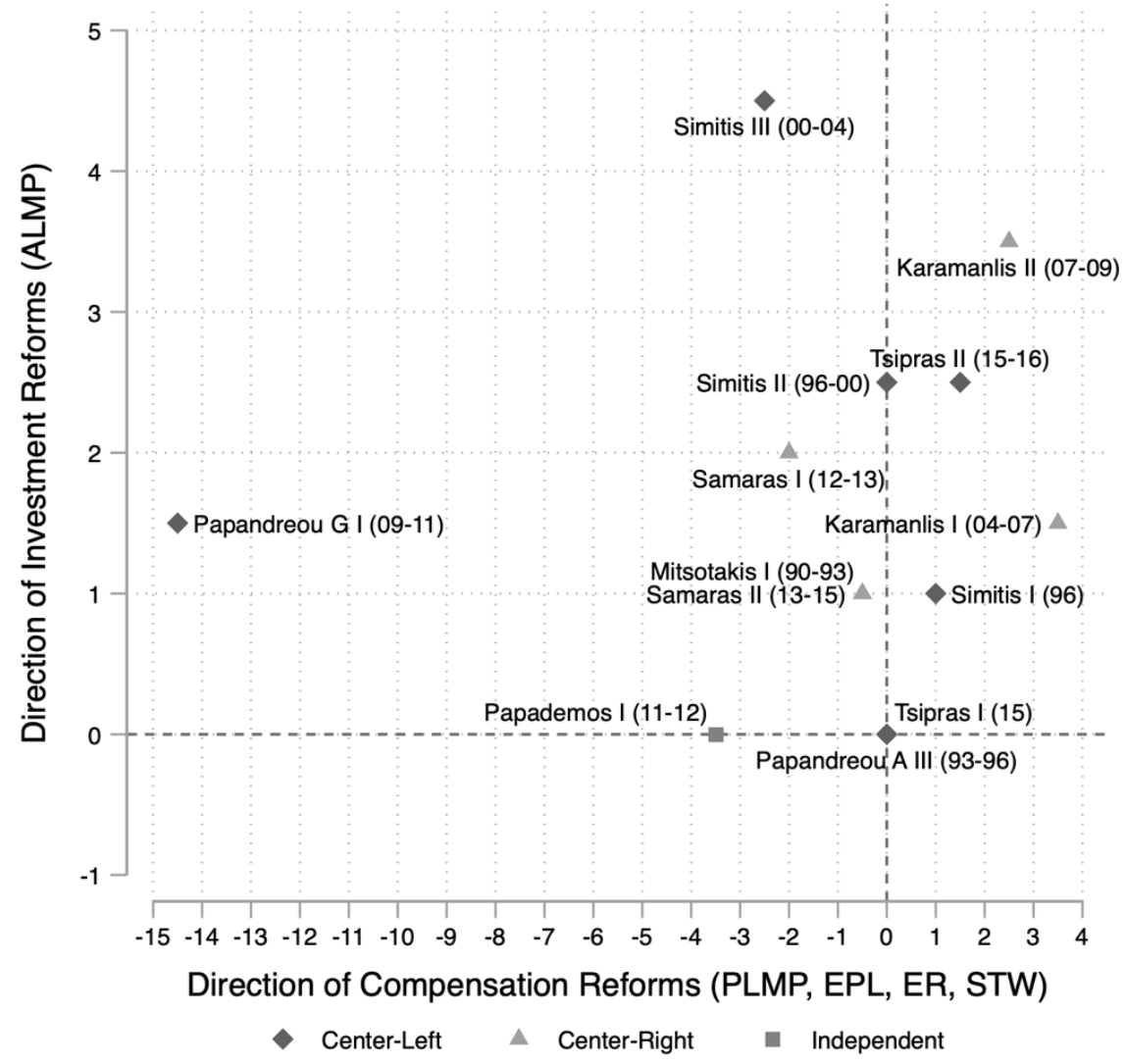

Figure 4.7: Labor Market Reforms in Greece by Cabinet

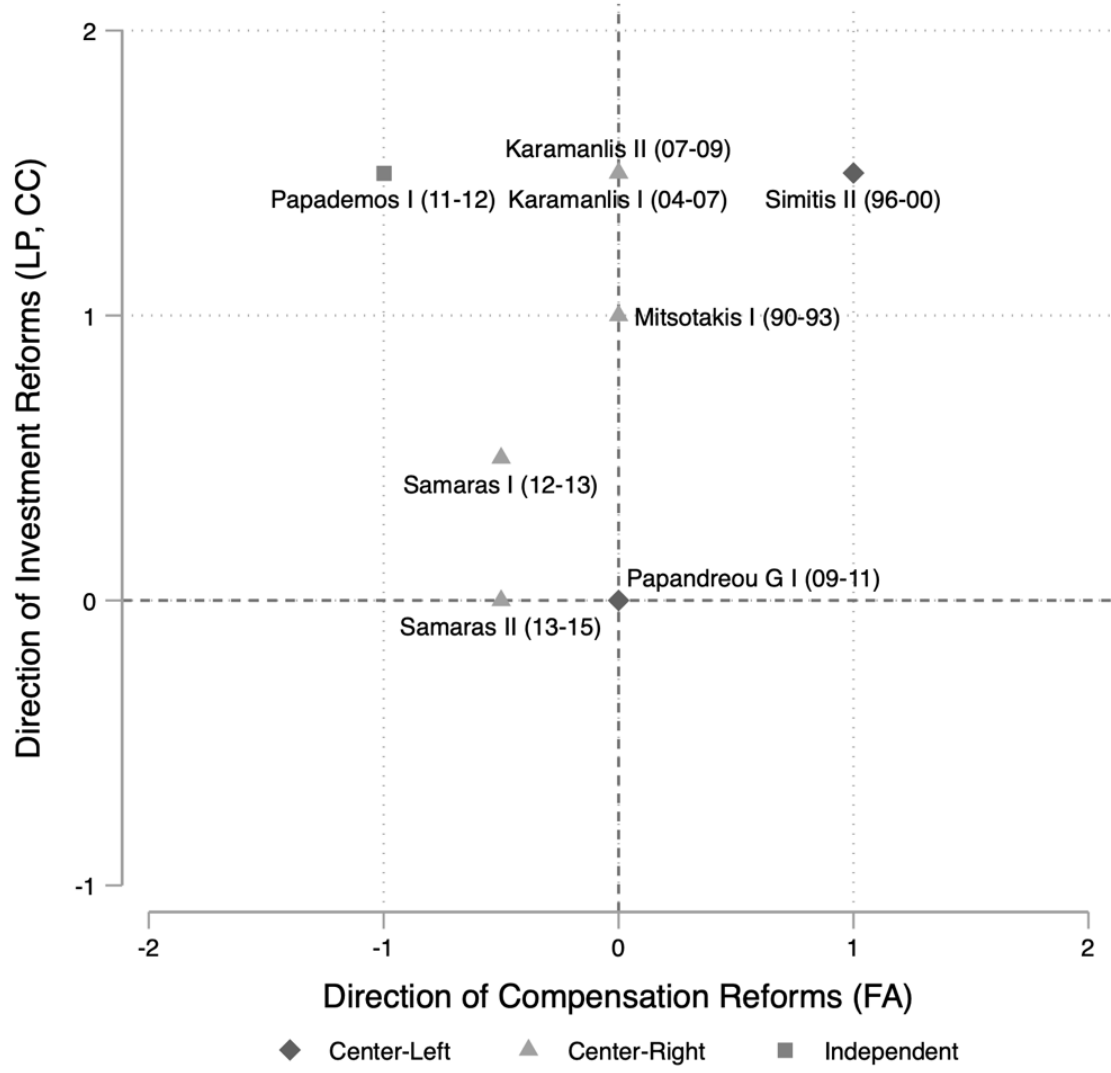

Figure 4.8: Family Policy Reforms in Greece by Cabinet 
At the height of the Greek crisis between 2009 and 2011, the PASOK government of Papandreou $G$ engaged in the massive retrenchment of EPL. The sheer intensity of retrenchment, which has also occurred in other dimensions of the welfare state (Perez \& Matsaganis, 2018; Petmesidou \& Glatzer, 2015), led to the almost complete obliteration of PASOK in the next election. Due to the mounting popular protests, both PASOK and ND agreed to delegate further austerity measures to a caretaker government. The short-lived caretaker government of Papademos continued down the same path and enacted further austerity reforms, except for some minor improvements in maternity leave. The following two ND governments of Samaras (2012-2015) were still under strict conditionality of the Troika, but welfare state retrenchment did not take place anymore in the dimension of labor market policy (Perez \& Matsaganis, 2018). It even allowed the second Samaras government and the incoming Tsipras government to increase social compensation again slightly and some activation measures, yet to a minimal degree.

Overall, there are little partisanship differences visible between the two main parties. Independent of the party in government, increasingly more ALMPs have been introduced over time. Austerity measures in Greece did not negatively affect the (underdeveloped) social investment dimension of labor market and family policies. Like in Portugal, ALMPs were excluded from retrenchment in the Memoranda of Understanding with the Troika. In most of these explicit and implicit agreements between Southern European governments and the European institutions, ALMPs were mentioned by international actors as a possible cure to high (youth) unemployment rates (Theodoropoulou, 2014). Nevertheless, ALMPs in Greece remain severely underdeveloped and lack financial resources. They almost exclusively focus on skill mobilization through employment assistance and job subsidies, and there are barely any programs aimed at skill creation through retraining programs.

It remains challenging to explain the variation of reforms in Greece by the composition of its government. Even during the good economic times of the early 2000s, there were barely any differences in the reform profiles of PASOK and ND. According to Matsaganis (2005), Greece is even among the family of Southern European welfare states a "deviant case". In terms of the theoretical framework of this project, social investment did not become politicized at all. The welfare state is characterized by a clientelistic mediation of access to resources, where certain social groups had access to special welfare privileges coupled with an ineffective public administration (Sotiropoulos, 2004). This is an implication of the Greek party system built to ensure the clientelistic distribution of political rents (Pappas, 2013). Consequently, 
programmatic competition between the two main parties is less important, and politics has been dominated by a small number of political families (Featherstone \& Papadimitriou, 2015). Hence, to some extent, even the precondition of programmatic party competition for social investment politics has not been met in the Greek context (see chapter 6 in volume I by Chen and Kitschelt [2021]). Given these features, it is less surprising to see little partisanship differences, and neither party can be characterized as a social investment protagonist.

\section{Conclusion}

Southern European countries experienced divergent social investment trajectories over the last decades. While Spain and Portugal have started to develop contours of a more inclusive social investment agenda, little progress has been made in Italy and Greece. This chapter's findings reveal that programmatic political competition and government partisanship play a role in accounting for these divergent trajectories.

In Spain, the center-left PSOE has developed into a social investment protagonist and aims to mobilize, preserve, and create human capabilities. In contrast, the center-right PP has followed more a strategy of market liberalism combined with a narrow focus on small improvements of leave policies and stricter workfare activation. Especially in the field of childcare and activation, the two main parties have divergent strategies, with the PP acting at times even as an antagonist to inclusive social investment reforms. In Portugal, the center-left PS is a social investment protagonist and emphasized skill creation and preservation through activation and leave policy. Unlike in Spain, the center-right PSD is a social investment consenter and sometimes also enacted activation and leave policy reforms, though to a smaller extent and usually with a stronger pro-market focus.

In Italy, center-right governments have done little with regards to social investment and acted mainly as social investment antagonists. Center-left governments initially also followed a more compensation-oriented strategy, but later shifted to act as social investment protagonists. However, the Italian center-left was (and still is) internally divided, confronted with tight budgetary constraints, and governments usually short-lived. Since center-right parties have dominated Italian politics most of the time and center-left cabinets shifted late towards social investment, activation and childcare policies remain underdeveloped. 
In contrast to the other three countries, it is difficult to identify a political party acting as a social investment protagonist in Greece. Neither PASOK nor ND has pushed for significant changes to family policies or a turn towards activation. Instead, social investment was not politicized at all in the Greek context, to some extent as a result of clientelistic party competition. Activation and childcare policies remain severely underdeveloped and, even if some reforms were implemented, they lack financial resources.

Political turmoil in the wake of the Eurozone crisis, the ongoing dire economic situation and the relatively weak dynamic of structural change towards a knowledge economy in Southern Europe paint a bleak picture for the further development of social investment in this region of Europe. Just when the contours of a tentative social investment agenda began to emerge in some Southern European countries, the Eurozone crisis unfolded and severely crippled a further expansion of social investment. Even though austerity measures did not negatively impact activation, leave, and childcare policies, the immediate budgetary constraints certainly put tight constraints on further substantial policy developments, even in those contexts (Spain and Portugal) where there are partisan protagonists of social investment. Once fiscal constraints can eventually be overcome, a core question remains: to what extent can an inclusive social investment coalition be formed in an ever more fragmented political landscape? It thus remains to be seen what social policy programs newly pivotal political parties, such as the Five Star Movement and Lega in Italy, Ciudadanos and Podemos in Spain, and Syriza in Greece, bring to the table and to what extent it alters the politics of social investment in Southern Europe. 


\section{References}

Albertini, M., \& Pavolini, E. (2015). Care policies in Italy between a national frozen landscape and local dynamism. In U. Ascoli \& E. Pavolini (Eds.), The Italian Welfare State in a European Perspective (pp. 133-156). Policy Press.

Bonoli, G. (2003). Social Policy through Labor Markets: Understanding National Differences in the Provision of Economic Security to Wage Earners. Comparative Political Studies, 36(9), 1007-1030.

Bonoli, G. (2007). Time matters postindustrialization, new social risks, and welfare state adaptation in advanced industrial democracies. Comparative Political Studies, 40(5), 495-520.

Bonoli, G. (2013). The origins of active social policy: Labour market and childcare policies in a comparative perspective. Oxford University Press.

Bürgisser, R. (2019). The Politics of Welfare State Recalibration in Continental and Southern Europe. Dissertation. European University Institute.

Bürgisser, R., \& Kurer, T. (2021). Insider-outsider representation and social democratic labor market policy. Socio-Economic Review 19(3), 1065-1094.

Cabrero, G. R. (2011). The consolidation of the Spanish welfare state (1975-2010). In A. M. Guillén \& M. León (Eds.), The Spanish welfare state in European context (pp. 17-38). Ashgate.

Culpepper, P. D. (2014). The political economy of unmediated democracy: Italian austerity under Mario Monti. West European Politics, 37(6), 1264-1281.

De Cecco, M. (2007). Italy's dysfunctional political economy. West European Politics, 30(4), 763 783.

Emmenegger, P., Häusermann, S., Palier, B., \& Seeleib-Kaiser, M. (Eds.). (2012). The age of dualization: The changing face of inequality in deindustrializing societies. Oxford University Press.

Escobedo, A., \& Wall, K. (2015). Leave policies in Southern Europe: Continuities and changes. Community, Work \& Family, 18(2), 218-235.

Esping-Andersen, G. (1990). The Three Worlds of Welfare Capitalism. Polity Press.

Featherstone, K., \& Papadimitriou, D. (2015). Prime Ministers in Greece: The Paradox of Power. Oxford University Press.

Ferrera, M. (1996). The 'Southern model' of welfare in social Europe. Journal of European Social Policy, 6, 17-37.

Ferrera, M., \& Gualmini, E. (2004). Rescued by Europe?: Social and labour market reforms in Italy from Maastricht to Berlusconi. Amsterdam University Press.

Ferrera, M., Jessoula, M., \& Fargion, V. (2013). At the roots of the Italian unbalanced welfare state. Unpublished Manuscript.

Hinrichs, K., \& Jessoula, M. (2012). Labour Market Flexibility and Pension Reforms: What Prospects for Security in Old Age? In K. Hinrichs \& M. Jessoula (Eds.), Labour Market Flexibility and Pension Reforms (pp. 1-25). Springer.

Kazepov, Y., \& Ranci, C. (2017). Is every country fit for social investment? Italy as an adverse case. Journal of European Social Policy, 27(1), 90-104.

Leibfried, S. (1993). Towards a European welfare state. New Perspectives on the Welfare State in Europe, 133-156. 
León, M. (2011). The quest for gender equality. In A. M. Guillén \& M. León (Eds.), The Spanish welfare state in European context (pp. 59-76). Ashgate.

Matsaganis, M. (2005). The limits of selectivity as a recipe for welfare reform: The case of Greece. Journal of Social Policy, 34(2), 235-253.

Matsaganis, M. (2011). The welfare state and the crisis: The case of Greece. Journal of European Social Policy, 21(5), 501-512.

Moreno, M. F. (2000). The Spanish development of southern European welfare. In S. Kuhnle (Ed.), Survival of the European Welfare State (pp. 146-165). Routledge.

Morgan, K. J. (2006). Working mothers and the welfare state: Religion and the politics of work-family policies in Western Europe and the United States. Stanford University Press.

Morgan, K. J. (2012). Promoting social investment through work-family policies. In N. Morel, B. Palier, \& J. Palme (Eds.), Towards a social investment welfare state (pp. 153-80). Policy Press.

Naldini, M. (2003). The family in the Mediterranean welfare states. Routledge.

Naldini, M., \& Saraceno, C. (2008). Social and family policies in Italy: Not totally frozen but far from structural reforms. Social Policy \& Administration, 42(7), 733-748.

Pappas, T. S. (2013). Why Greece Failed. Journal of Democracy, 24(2), 31-45.

Perez, S. A., \& Matsaganis, M. (2018). The political economy of austerity in Southern Europe. New Political Economy, 23(2), 192-207.

Petmesidou, M. (2017). Welfare reform in Greece: A major crisis, crippling debt conditions, and stark challenges ahead. In P. Taylor-Gooby, B. Leruth, \& H. Chung (Eds.), After austerity: Welfare state transformation in Europe after the great recession (pp. 155-179).

Petmesidou, M., \& Glatzer, M. (2015). The crisis imperative, reform dynamics and rescaling in Greece and Portugal. European Journal of Social Security, 17(2), 158-181.

Rhodes, M. (1997). Southern European Welfare States: Between Crisis and Reform. Psychology Press.

Sacchi, S. (2018). The Italian welfare state in the crisis: Learning to adjust? South European Society and Politics, 23(1), 29-46.

Saraceno, C. (1994). The Ambivalent Familism of the Italian Welfare State. Social Politics, 1(1), 60-82.

Sotiropoulos, D. A. (2004). Southern European public bureaucracies in comparative perspective. West European Politics, 27(3), 405-422.

Theodoropoulou, S. (2014). Has the EU become more intrusive in shaping national welfare state reforms? Evidence from Greece and Portugal. Brussels: ETUI.

Wall, K. (2016). Family policies in Portugal. In A (s) problemática (s) da natalidade em Portugal: Uma questão social, económica e política (pp. 191-201). Imprensa de Ciências Sociais.

Wall, K., \& Escobedo, A. (2009). Portugal and Spain: Two pathways in Southern Europe. In S. B. Kamerman \& P. Moss (Eds.), The politics of parental leave policies. Children, parenting, gender and the labour market (pp. 207-226). Policy Press.

Watson, S. E. (2015). The Left Divided: The Development and Transformation of Advanced Welfare States. Oxford University Press, USA. 